\title{
Evaluation of potential biotin interference in immunogenicity testing
}

\author{
Alexander Pöhler*,1, Janine Faigle ${ }^{1} \&$ Roland F Staack ${ }^{1}$ \\ ${ }^{1}$ Roche Pharma Research \& Early Development (pRED), Pharmaceutical Sciences, Bioanalytical R\&D, Roche Innovation Center \\ Munich, Roche Diagnostics GmbH, Nonnenwald 2, 82377 Penzberg, Germany \\ *Author for correspondence: Tel.: +49 885660 19024; alexander.poehler@roche.com
}

\begin{abstract}
Aim: One-step bridging assays typically used for immunogenicity testing may be challenged by biotin interference (BI) caused by widely available dietary supplementation or medically prescribed high-dose therapies. We investigated BI in two one-step antidrug antibody assays. Results: Both assays showed biotinrelated interference, with the peptide-based assay being less affected than the antibody-based assay. BI was reduced by minimum required dilution adaption from 10 to $1 \%$ and eliminated by a depletion-based sample pretreatment. Conclusion: Increased biotin levels have the potential to interfere with immunogenicity testing methods that use biotin technology. Since the extent of interference differs from assay to assay, assessment during development phase is recommended. Minimum required dilution adjustment or sample pretreatment are options to reduce or eliminate BI.
\end{abstract}

First draft submitted: 20 March 2019; Accepted for publication: 10 April 2019; Published online: 9 May 2019

Keywords: antidrug antibody $\bullet$ biotin $\bullet$ ELISA $\bullet$ immunogenicity $\bullet$ interference

Biotin is a water-soluble vitamin and serves as a coenzyme for carboxylase enzymes in humans. Physiological serum concentration of biotin and catabolites after usual dietary intake is approximately $0.5 \mathrm{nmol} / \mathrm{l}(0.12 \mathrm{ng} / \mathrm{ml})[1]$. In addition to that, biotin-containing dietary supplements are sold to improve hair, nails and skin.

Results from the 1986 National Health Interview Survey indicate that approximately 17\% of US adults take a supplement containing biotin [2]. In the mid 2000s, approximately $33 \%$ of US adults took a multivitaminmultimineral supplement, that may contain biotin, on a daily basis [3]. The majority and most common supplements contain up to $100 \mu \mathrm{g}$ biotin in the form of multivitamin tablets [4,5]. Some single-agent preparations contain up to $10 \mathrm{mg}$ biotin [6].

Remarkably high doses of biotin, namely $300 \mathrm{mg} /$ day, have been proposed for the treatment of patients with progressive multiple sclerosis [7]. While a single dose of $300 \mathrm{mg}$ biotin led to a peak plasma concentration of $823 \pm 303 \mathrm{ng} / \mathrm{ml}$ biotin in a randomized crossover trial in healthy adults [8], a therapeutic administration of three single doses of $100 \mathrm{mg}$ per day may result in significantly lower peak concentrations. The exposure was observed $1-2 \mathrm{~h}$ post oral administration, indicating rapid absorption and distribution, and biotin was quickly eliminated, indicated by calculated elimination half-lives that varied between 7.8 and $18.8 \mathrm{~h}[8]$.

Many ligand-binding assays (LBA), which are used in the bioanalytical field, utilize the streptavidin (SA)-biotin interaction due to its high-affinity properties as well as convenient biotinylation methods available, for example, Gyrolab's bead-based microfluid platform [9] or plate-based methods like electrochemiluminescence applications from Meso Scale Discovery [10] as well as ELISA [11].

Depending on the assay format used in such technologies, assays might be prone to biotin interference (BI). Most susceptible are formats in which residual biotin can compete with the biotinylated assay reagents on SA-coated surfaces, resulting in a biotin-dependent loss of signal.

Particularly in the field of immunogenicity testing, one-step LBAs, which might be prone to BI, are used for the detection of ADAs (antidrug antibodies). Consequently, such an interference can be a challenge because the presence of increased biotin levels may lead to altered screening results.

For a detailed evaluation, two one-step bridging antidrug antibody (ADA) assays were used to investigate potential interference of elevated serum/plasma biotin levels and its impact on immunogenicity test results (Figure 1). 

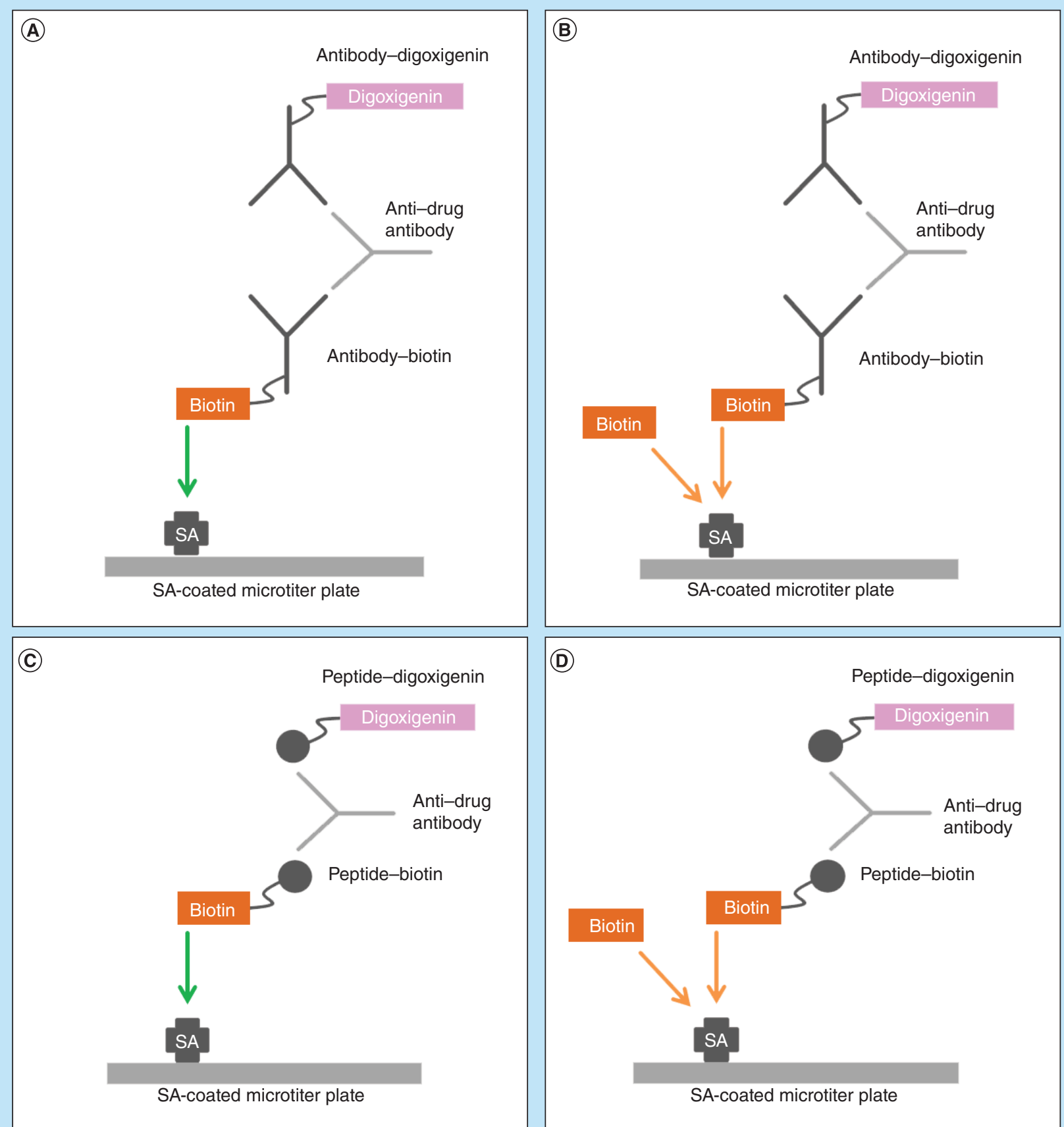

(D)

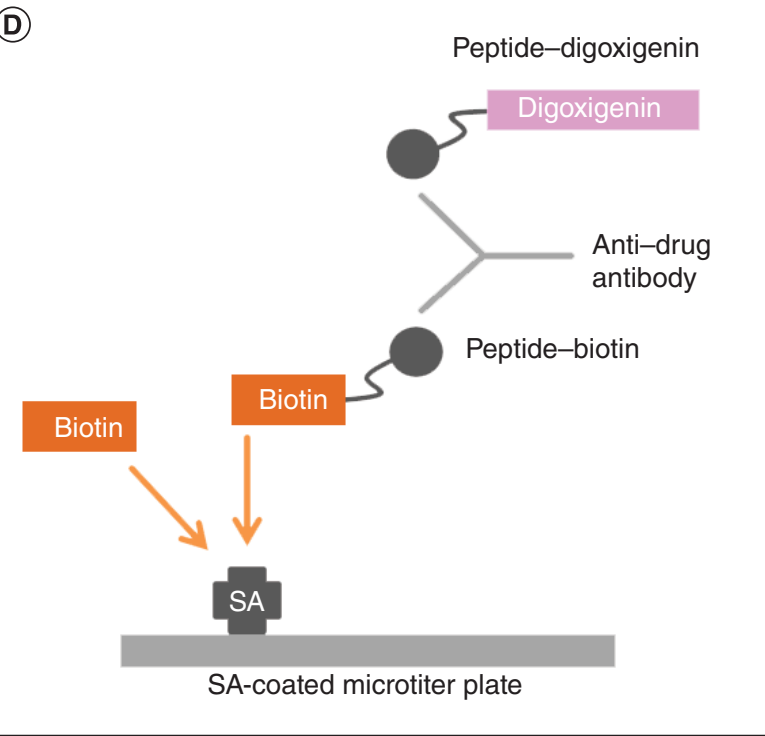

Figure 1. Principle of antibody-based and peptide-based antidrug antibody assay with and without biotin interference. (A) Formed immune complexes, consisting of antibody-digoxigenin/antidrug antibody/antibody-biotin, are able to bind to an SA-coated microtiter plate and generate a signal. (B) In presence of residual biotin, formed immune complexes compete with biotin for SA binding sites, leading to fewer bound complexes and signal loss. (C) Formed immune complexes (peptide-digoxigenin/antidrug antibody/peptide-biotin) are able to bind to an SA-coated microtiter plate and generate a signal. (D) In presence of residual biotin, formed immune complexes compete with biotin for SA binding sites, leading to fewer bound complexes and signal loss. SA: Streptavidin. 


\section{Experimental}

\section{Positive controls}

A polyclonal rabbit-derived antibody ( $\mathrm{pAb}<\mathrm{Ab}>\mathrm{Rb}$; Roche Diagnostics $\mathrm{GmbH}$, Penzberg, Germany) directed against a therapeutic monoclonal drug candidate with a molecular weight of approximately $150 \mathrm{kDa}$ was used as positive control (PC) in the antibody (Ab)-based ELISA. It was dissolved at $3.1 \mathrm{mg} / \mathrm{ml}$ in an aqueous solution of $50 \mathrm{mM}$ potassium phosphate (Merck Chemicals GmbH, Darmstadt, Germany) and $150 \mathrm{mM}$ sodium chloride (Merck Chemicals GmbH), pH 7.5.

A polyclonal goat-derived $\mathrm{Ab}(\mathrm{pAb}<$ peptide $>\mathrm{G}$; Roche Diagnostics $\mathrm{GmbH})$ directed against a therapeutic peptide drug candidate with a molecular weight of approximately $1.5 \mathrm{kDa}$ was used as $\mathrm{PC}$ in the peptide-based ELISA. It was dissolved at $1.15 \mathrm{mg} / \mathrm{ml}$ in an aqueous solution of $50 \mathrm{mM}$ potassium phosphate, $150 \mathrm{mM}$ potassium chloride (Merck Chemicals GmbH) and 6.5\% (w/v) sucrose (Merck Chemicals GmbH), pH 7.5.

\section{Human matrices}

Human pooled serum from mixed gender was obtained from TRINA Bioreactives AG (Nänikon, Switzerland).

Human pooled K3EDTA plasma from mixed gender was obtained from Sera Laboratories International Ltd, Haywards Heath, UK.

15 selected human study samples were obtained from a Phase I single ascending dose study in healthy male and female adults. The time points of the subset varied between 1.5 and $2184 \mathrm{~h}$ postdose, and represent a range of low-, medium- and high level of immune responses. After collection, blood samples were centrifuged and obtained serum fractions were stored frozen $\left(-70^{\circ} \mathrm{C}\right)$ until further analysis.

\section{Ab-based ADA assay}

The Ab-based ELISA involved an SA-coated microtiter plate (MTP; Microcoat Biotechnologie GmbH, Bernried am Starnberger See, Germany), which was blocked $1 \mathrm{~h}$ at room temperature (450 rpm) with $200 \mu \mathrm{l}$ /well aqueous solution of $10 \%(\mathrm{w} / \mathrm{v})$ milk powder (Merck Chemicals GmbH) and $0.05 \%(\mathrm{v} / \mathrm{v})$ Tween20 (Roche Diagnostics $\mathrm{GmbH}$ ). After three washing steps using $300 \mu \mathrm{l} 1 \times \mathrm{PBS}$ (Roche Diagnostics $\mathrm{GmbH}$ ) containing $0.05 \%$ (v/v) Tween20, samples with formed complexes were incubated $1 \mathrm{~h}$ at room temperature (450 rpm) on the MTP.

Complexes were formed by spiking 39-2500 ng/ml pAb $<\mathrm{Ab}>\mathrm{Rb}$ together with $0.5-1200 \mathrm{ng} / \mathrm{ml} \mathrm{D-Biotin}$ (DSM Nutritional Products Ltd, Kaiseraugst, Switzerland) in human pooled serum and diluted 1:10 or 1:100 using $1 \times$ PBS containing $0.5 \%(\mathrm{w} / \mathrm{v})$ bovine serum albumin (BSA; Roche Diagnostics $\mathrm{GmbH}$ ), together with $1000 \mathrm{ng} / \mathrm{ml} \mathrm{Ab-biotin} \mathrm{and} 1000 \mathrm{ng} / \mathrm{ml} \mathrm{Ab-digoxigenin} \mathrm{and} \mathrm{incubated} \mathrm{overnight} \mathrm{(16-18} \mathrm{h)} \mathrm{at} \mathrm{room} \mathrm{temperature}$ (450 rpm).

Selected human ADA-containing sera were processed in the same way.

After three washing steps, $5 \mathrm{mU} / \mathrm{ml}$ horseradish peroxidase (HRP)-labeled antidigoxigenin Fab fragments (< digoxigenin > HRP; Roche Diagnostics GmbH) in $1 \times$ PBS with $0.5 \%(\mathrm{w} / \mathrm{v})$ BSA were added to the MTP and incubated for $1 \mathrm{~h}$ at room temperature $(450 \mathrm{rpm})$. After three washing steps, substrate reaction was carried out by adding $100 \mu \mathrm{l} /$ well 3,3',5,5'-Tetramethylbenzidine solution (Roche Diagnostics GmbH) and monitored at a wavelength of $680 \mathrm{~nm}$ with a reference wavelength of $450 \mathrm{~nm}$ until optical density of the highest calibrator $(2500 \mathrm{ng} / \mathrm{ml} \mathrm{pAb}<\mathrm{Ab}>\mathrm{Rb}$ ) reached approximately 0.65 absorbance units (AU) and then stopped using $50 \mu \mathrm{l} /$ well $1 \mathrm{M}$ sulfuric acid (Merck Chemicals $\mathrm{GmbH}$ ). Optical density at approximately 2.0 AU was measured at a wavelength of $450 \mathrm{~nm}$ with a reference wavelength of $690 \mathrm{~nm}$ on a microplate reader (Sunrise; Tecan, Switzerland). The final absorbance was calculated as follows: absorbance $(450 \mathrm{~nm})$ - absorbance $(690 \mathrm{~nm})$.

This method was developed and qualified according to recommendations $[12,13]$.

\section{Peptide-based ADA assay}

The peptide-based ELISA involved an SA-coated MTP on which formed complexes were incubated for $1 \mathrm{~h}$ at room temperature (450 rpm).

Complexes were formed by spiking 39-2500 ng/ml pAb $<$ peptide $>$ G together with $0.5-1200 \mathrm{ng} / \mathrm{ml}$ D-Biotin in human pooled K3EDTA plasma and diluted 1:10 or 1:100 using universal ELISA buffer (Roche Diagnostics $\mathrm{GmbH}$ ), together with $300 \mathrm{ng} / \mathrm{ml}$ peptide-biotin and $300 \mathrm{ng} / \mathrm{ml}$ peptide-digoxigenin, and incubated overnight $(16-18 \mathrm{~h})$ at room temperature $(450 \mathrm{rpm})$. 

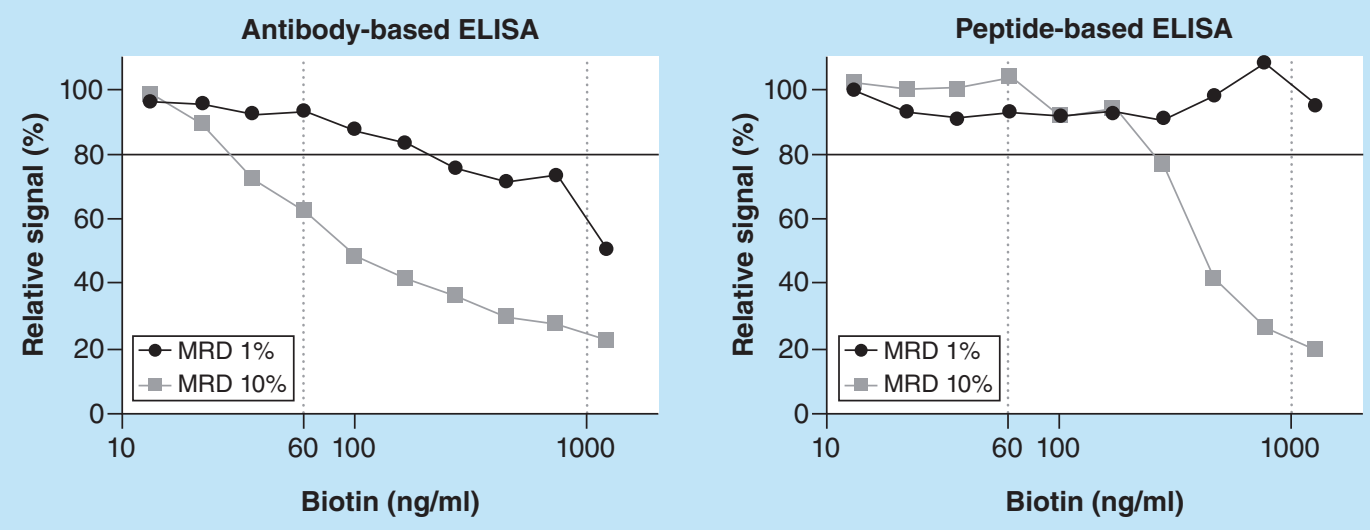

Figure 2. Relative signal of samples spiked with $39 \mathrm{ng} / \mathrm{ml}$ positive control and increasing biotin concentrations compared with a sample spiked with only $39 \mathrm{ng} / \mathrm{ml}$ positive control.

MRD: Minimum required dilution.

After three washing steps using $300 \mu \mathrm{l} 1 \times$ PBS containing $0.05 \%(\mathrm{v} / \mathrm{v})$ Tween $20,30 \mathrm{mU} / \mathrm{ml}$ $<$ digoxigenin $>\mathrm{HRP}$ in $1 \times$ PBS with $0.5 \%(\mathrm{w} / \mathrm{v})$ BSA was added to the MTP and incubated for $1 \mathrm{~h}$ at room temperature (450 rpm).

After three washing steps, substrate reaction was carried out by adding $100 \mu \mathrm{l} /$ well 2,2'-azino-bis(3ethylbenzothiazoline-6-sulfonic acid solution (Roche Diagnostics $\mathrm{GmbH}$ ), and optical density was measured at a wavelength of $405 \mathrm{~nm}$ with a reference wavelength at $490 \mathrm{~nm}$ on a microplate reader (Sunrise; Tecan) until the highest calibrator $(2500 \mathrm{ng} / \mathrm{ml} \mathrm{pAb}<$ peptide $>\mathrm{G})$ reached approximately $2.0 \mathrm{AU}$. The final absorbance was calculated as follows: absorbance ( $405 \mathrm{~nm})$ - absorbance $(490 \mathrm{~nm})$.

This method was developed and qualified according to recommendations [12,13].

\section{Sample pretreatment}

The $40 \mu \mathrm{l}$ of each sample containing 39-2500 $\mathrm{ng} / \mathrm{ml} \mathrm{pAb}<\mathrm{Ab}>\mathrm{Rb}$ and $0.5-1200 \mathrm{ng} / \mathrm{ml}$ D-Biotin in human pooled serum was mixed together with $10 \mu \mathrm{l} \mathrm{SA-coated} \mathrm{magnetic} \mathrm{beads} \mathrm{(Roche} \mathrm{Diagnostics} \mathrm{GmbH)} \mathrm{and} \mathrm{incubated}$ $2 \mathrm{~h}$ at room temperature $(700 \mathrm{rpm}$ ). Beads were then separated using a KingFisher Flex purification system (Thermo Fisher Scientific, MA, USA) and supernatants were used for analysis according to the protocol of the Ab-based ADA assay.

\section{Results}

In this study, we evaluated potential BI in two one-step ADA bridging ELISAs, each tested at 10 and $1 \%$ human matrix (minimum required dilution [MRD]; 1:10 and 1:100, respectively). In detail, we assessed biotin concentration-dependent signal quenching of samples spiked with polyclonal ADA surrogate PC and 15 ADApositive human study samples. Due to limited specimen availability, the latter were only tested in the Ab-based assay. After an oral dose of 5-10 mg biotin which, as stated above, represents the upper range of over-the-counter dosages, maximal serum concentrations of $60 \mathrm{ng} / \mathrm{ml}$ biotin can be produced [4]. To mimic such a worst case situation this biotin concentration was chosen to evaluate the influence on a sample containing $39 \mathrm{ng} / \mathrm{ml}$ PC.

The analysis in the Ab-based assay resulted in a signal quenching of 37\% in the $10 \% \mathrm{MRD}$ variant, but showed no relevant quenching effect in the $1 \%$ MRD variant (Figure 2, left), as it is within typical acceptance criteria for bioanalytical methods $[13,14]$.

The analysis of an analogously prepared PC sample with $60 \mathrm{ng} / \mathrm{ml}$ biotin in the peptide-based assay did not result in relevant signal quenching regardless of MRD variants (Figure 2, right).

However, the addition of $1000 \mathrm{ng} / \mathrm{ml}$ biotin to the PC sample, which represents the intake of a $300 \mathrm{mg}$ single dose of biotin [8], resulted in a signal quenching of $75 \%$ (10\% MRD) and 40\% (1\% MRD) in the Ab-based assay, respectively (Figure 2, left).

Although BI was reduced by MRD adjustment, signal quenching is still relevant in this case. 
Figure 3. Antidrug antibody-positive human study samples $(n=15)$ were analyzed using the antibody-based antidrug antibody ELISA after the addition of 60 or $1000 \mathrm{ng} / \mathrm{ml}$ biotin. The results are given as mean recovery values relative to respective natively analyzed samples.

MRD: Minimum required dilution.

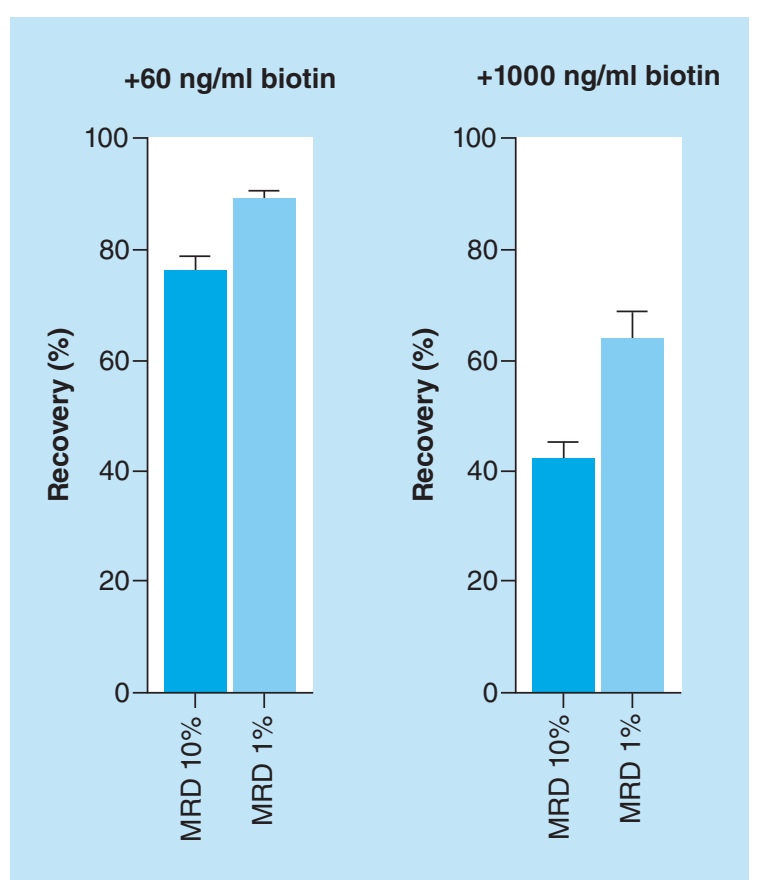

The analysis of an analogously prepared PC sample with $1000 \mathrm{ng} / \mathrm{ml}$ biotin in the peptide-based assay resulted in a signal quenching of $75 \%$ in the $10 \%$ MRD variant, but showed no relevant quenching effect in the $1 \% \mathrm{MRD}$ variant (Figure 2, right).

These results indicate that $\mathrm{BI}$ can be reduced by higher sample dilutions.

To characterize BI further, a set of ADA-positive human study samples $(n=15)$ was used as a more representative ADA surrogate. The Ab-based assay was used in both MRD variants to analyze samples natively and after the addition of 60 or $1000 \mathrm{ng} / \mathrm{ml}$ biotin.

The aim was to vindicate whether the BI previously observed can be reduced using higher sample dilutions in ADA-positive specimens.

The addition of $60 \mathrm{ng} / \mathrm{ml}$ biotin to ADA-positive human sera resulted in a mean signal quenching of $24 \%$ (10\% MRD) and $11 \%(1 \% \mathrm{MRD})$, respectively (Figure 3, left).

The addition of $1000 \mathrm{ng} / \mathrm{ml}$ biotin to the samples resulted a mean signal quenching of $58 \%(10 \% \mathrm{MRD})$ and $36 \%$ (1\% MRD), respectively (Figure 3, right).

These results confirm the observation that BI can be reduced by higher sample dilutions.

For the removal of potentially present biotin from samples and subsequent elimination of biotin-related assay interferences a sample pretreatment (SPT) method was assessed (Figure 4). The SPT involves SA-coated magnetic beads to bind biotin, as well as possibly occurring biotin metabolites that have full or residual affinity to SA. We chose the $10 \%$ MRD variant of the Ab-based ADA assay for this experiment, as it showed a more pronounced interference.

Originally quenched assay signals from samples with $39 \mathrm{ng} / \mathrm{ml} \mathrm{PC}$ and increasing biotin concentrations showed no relevant quenching effect after SPT (Figure 5), indicating complete removal of biotin from the sample up to a concentration of $1200 \mathrm{ng} / \mathrm{ml}$.

\section{Discussion}

One-step bridging assays typically used for immunogenicity testing may be challenged by BI caused by widely available dietary supplementation or medically prescribed high-dose therapies. Therefore, we investigated BI in two one-step ADA assays that use biotin technology.

Due to their availability, over-the-counter biotin-containing dietary supplementations are commonly consumed $[2,3]$. The majority of dietary supplements as in the case of multivitamin tablets contain up to $100 \mu \mathrm{g}$ biotin but can in rare cases range up to $10 \mathrm{mg}$ biotin [4,6]. In contrast, extreme doses of $300 \mathrm{mg}$ biotin represent rare medically prescribed high-dose therapies for special cases and are therefore not widely used [8]. 


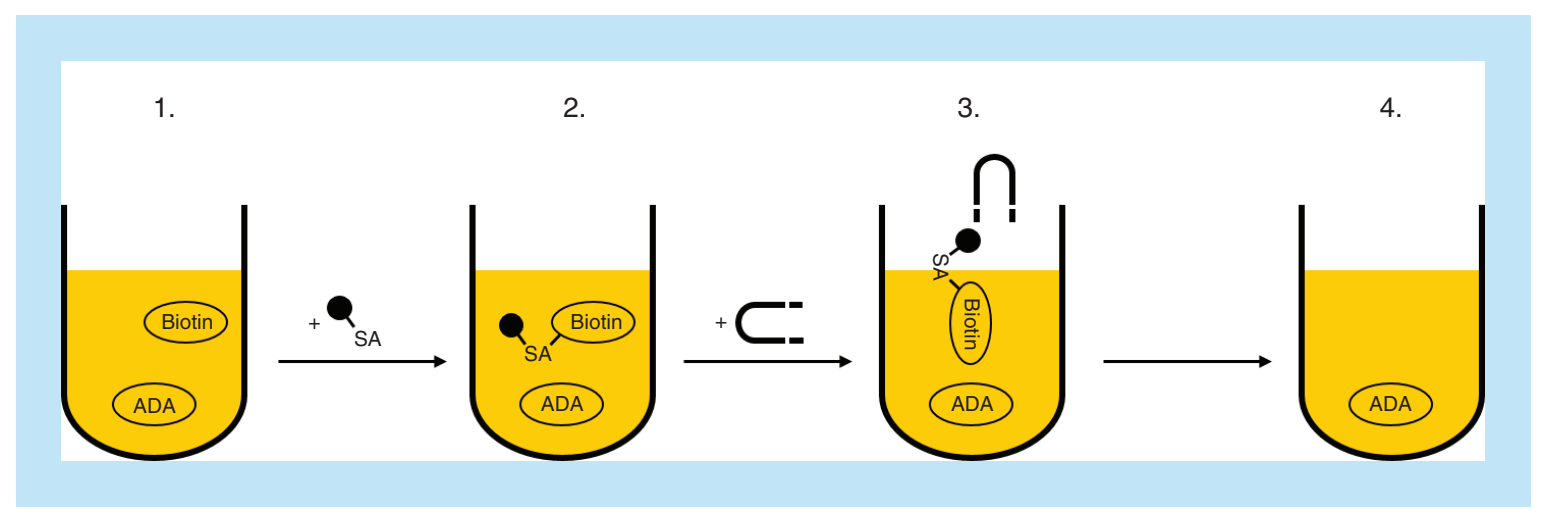

Figure 4. Sample pretreatment workflow. Samples with possibly occurring antidrug antibody and biotin (1) are incubated together with streptavidin-coated magnetic beads (2). Formed complexes consisting of bead-streptavidin-biotin are removed by a magnet (3) and biotin-depleted samples are obtained (4). ADA: Antidrug antibody; SA: Streptavidin.

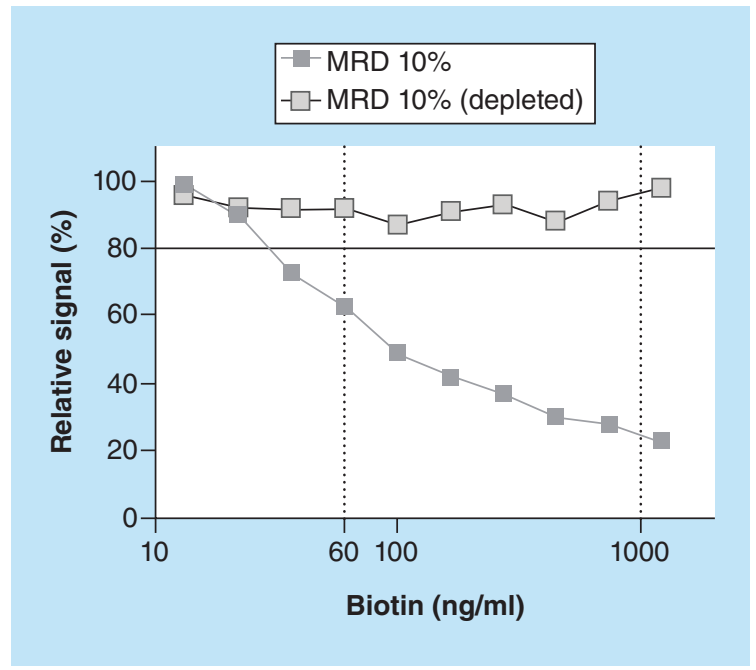

Figure 5. Samples spiked with $39 \mathrm{ng} / \mathrm{ml}$ positive control and increasing biotin concentrations were analyzed using the antibody-based ELISA at $10 \%$ minimum required dilution. Samples were analyzed natively and after sample pretreatment (depleted). MRD: Minimum required dilution.

In addition, most patients are likely to report the intake of a medically prescribed high-dose therapy rather than a supplementation with dietary pills from a grocery store, which would make options such as sample timing possible. For this reason, and due to the rare use of very high biotin doses, the relevance of extreme serum levels like $1000 \mathrm{ng} / \mathrm{ml}$ could be low in reality.

In this study, we focused mainly on two key biotin concentrations. Namely $60 \mathrm{ng} / \mathrm{ml}$ representing the intake of a highly concentrated dietary biotin supplementation with 5-10 mg biotin [4], and $1000 \mathrm{ng} / \mathrm{ml}$ representing the intake of a $300 \mathrm{mg}$ single dose of biotin [8].

Because of the wide distribution and potentially unknown consumption of dietary biotin supplementation, we consider biotin levels in the $60 \mathrm{ng} / \mathrm{ml}$ range to be an important test parameter in immunogenicity testing methods that use biotin technology.

To investigate BI at sensitive conditions and also comply with the US FDA's ADA assay sensitivity recommendation of at least $100 \mathrm{ng} / \mathrm{ml}$ [13], we chose a concentration of $39 \mathrm{ng} / \mathrm{ml} \mathrm{PC} \mathrm{for} \mathrm{spiking} \mathrm{experiments.}$

The analysis of a sample spiked with $39 \mathrm{ng} / \mathrm{ml} \mathrm{PC}$ and $60 \mathrm{ng} / \mathrm{ml}$ biotin in the Ab-based assay resulted in a signal quenching of $37 \%$ in the $10 \%$ MRD variant and improved to a signal quenching of $6 \%$ in the $1 \%$ MRD variant.

This improvement can be attributed to the higher dilution and associated reduction of biotin molecules in the assay. The higher dilution of 1:100 also has the advantage of improved drug tolerance by shifting equilibrium of ADA-drug complexes to a more free form of ADA and agrees with the current FDA recommendation regarding MRD selection [13]. On the contrary, higher dilutions may reduce assay sensitivity. In addition, we observed a different degree of interference from assay to assay. Namely, in the peptide-based assay, the analysis of an 
analogously prepared PC sample with $60 \mathrm{ng} / \mathrm{ml}$ biotin did not result in relevant signal quenching regardless of MRD variants.

This observation of the different degree of interference might be mainly due to higher reagent pressure relative to the SA binding sites as the peptide-based assay runs with 30-fold more biotinylated molecules compared with the Ab-based assay (200 vs $6.7 \mathrm{nM}$ ). The 100-fold smaller molecular weight of the peptide with its faster rate of diffusion might also be a contributing factor. These differences in type and concentration of assay reagents seemingly outweigh the effect of difference in biotinylation, as the multibiotinylation of the Ab, in contrast to the monobiotinylation of the peptide, theoretically should increase the likelihood of binding the complex to the SA surface, which may lead to slightly reduced interference.

We also confirmed improved BI by higher dilutions with a panel of $15 \mathrm{ADA}$-positive human study samples. The addition of $60 \mathrm{ng} / \mathrm{ml}$ biotin to ADA-positive human sera resulted in a mean signal quenching of $24 \%$ (10\% MRD) relative to unspiked samples. After switching to the $1 \% \mathrm{MRD}$ variant of the same assay, mean signal quenching improved to $11 \%$.

Although the signal quenching relating to $1000 \mathrm{ng} / \mathrm{ml}$ biotin could be inverted by MRD adjustment in the peptide-based assay, results from the Ab-based assay with ADA surrogate samples, as well as from experiments using ADA-positive study samples, still showed relevant signal quenching despite the higher dilution.

These results demonstrate that the usage of higher dilutions brings an improvement regarding BI, but does not represent a universal solution for very high biotin levels, for example, due to high-dose therapies. In such rare cases, if there is knowledge about a high-dose biotin therapy being applied to patients, SPT can be considered to eliminate even very high biotin serum levels. Such methods to deplete biotin from samples using SA-coated magnetic micro particles have already been developed and successfully applied to suppress biotin influence in competitive and sandwich immunoassays in the field of laboratory medicine [15].

The advantage of these methods lies in the additional elimination of possibly occurring metabolites that have full or residual affinity to SA, such as bisnorbiotin or biotin sulfoxide [1]. We chose SA-coated magnetic beads not only for convenient removal of biotin from the sample by a magnet but for their high binding capacity, but in principle any SA-coated surface with sufficient biotin binding capacity could be used.

To further minimize interference from biotin, we recommend to consider the guidance on washout periods by Grimsey et al. [4].

Generally, it is important for assay developers to be aware of potential BI in LBA that use biotin-SA technology. Therefore, it is desirable and beneficial for spiking experiments to be timely performed during development phase to enable clear results for cases involving biotin intake. A recent FDA safety communication regarding BI in lab tests suggests interference investigation up to at least $1200 \mathrm{ng} / \mathrm{ml}$ in assays that use biotin technology [16]. This recommendation should also be considered by the bioanalytical community.

\section{Conclusion}

In summary, we assessed biotin-related signal quenching of samples spiked with polyclonal ADA surrogate PC in two one-step ELISA methods used for immunogenicity testing. Biotin concentration-dependent signal quenching could be observed in both assays and was further confirmed with ADA-positive human study samples. Based on our results, we suggest to have increased awareness of potential BI in LBA technologies using the biotin-SA technology and assay formats, which might be susceptible, for example, one-step bridging assays that are typically used for immunogenicity testing. Early investigation during assay development is recommended and if possible an MRD adjustment to $1 \%$ should be considered. Also, if there is knowledge about a high-dose biotin therapy being applied, SPT can be considered in order to eliminate BI. In addition to that, a sufficient time span between the last biotin application and sampling is advised.

\section{Future perspective}

Immunogenicity testing of a new therapeutic drug candidate is an important part of the drug-development process. In cases of an immune response, detailed knowledge of the ADA formation is required to enable finding of potential correlations with efficacy or safety events. The bioanalytical methods used for immunogenicity testing are of particular importance, since they provide the required information. The data must be unequivocal, without any technological bias, such as the BI on LBA platforms using the biotin-SA technology.

The reported evaluation will help to increase awareness of the potential BI within the bioanalytical community. Recognition of this potential interference is important and implementation of BI testing strategy as part of assay 
development can be critical. The use of the proposed options such as adaptation of the MRD or SPT will enable the generation of unequivocal $\mathrm{ADA}$ data and thus enable optimal immunogenicity testing.

\section{Executive summary}

Background

- We investigated biotin interference in two one-step antidrug antibody (ADA) assays.

Results

- We observed biotin concentration-dependent signal quenching of samples spiked with polyclonal ADA surrogate-positive controls in both assays, that was further confirmed with ADA-positive human study samples.

- Biotin interference was reduced by minimum required dilution adaption from 10 to $1 \%$ and removed by depletion-based sample pretreatment.

\section{Conclusion}

- Interference assessment for individual assays during the development phase is recommended.

\section{Acknowledgments}

The authors thank N Tschauder, S Challand, M Richter and C Bruecklmayr for fruitful discussion and technical support.

Financial \& competing interests disclosure

All authors are employees of Roche Diagnostics GmbH. Some authors are owners of Roche bonus shares and profit certificates. The authors have no other relevant affiliations or financial involvement with any organization or entity with a financial interest in or financial conflict with the subject matter or materials discussed in the manuscript apart from those disclosed.

No writing assistance was utilized in the production of this manuscript.

\section{Open access}

This work is licensed under the Attribution-NonCommercial-NoDerivatives 4.0 Unported License. To view a copy of this license, visit http://creativecommons.org/licenses/by-nc-nd/4.0/

\section{References}

1. Zempleni J, Wijeratne SS, Hassan YI. Biotin. Biofactors 35(1), 36-46 (2009).

2. Moss AJ, Levy AS, Kim I, Park YK. Use of vitamin and mineral supplements in the United States: current users, types of products, and nutrients. Advance Data 174, 1-20 (1989).

3. Bailey RL, Gahche JJ, Lentino CV et al. Dietary supplement use in the United States, 2003-2006. J. Nutr. 141(2), 261-266 (2011).

4. Grimsey P, Frey N, Bendig G et al. Population pharmacokinetics of exogenous biotin and the relationship between biotin serum levels and in vitro immunoassay interference. Int. J. Pharmacokinet. 2(4), 247-256 (2017).

5. Katzman BM, Lueke AJ, Donato LJ, Jaffe AS, Baumann NA. Prevalence of biotin supplement usage in outpatients and plasma biotin concentrations in patients presenting to the emergency department. Clin. Biochem. 60, 11-16 (2018).

6. Biotin H Forte, $10 \mathrm{mg}$ (2019). https://haare-biotin.de

7. Sedel F, Papeix C, Bellanger A et al. High doses of biotin in chronic progressive multiple sclerosis: a pilot study. Mult. Scler. Relat. Disord. 4(2), 159-169 (2015).

8. Peyro Saint PL, Debruyne D, Bernard D, Mock DM, Defer GL. Pharmacokinetics and pharmacodynamics of MD1003 (high-dose biotin) in the treatment of progressive multiple sclerosis. Expert Opin. Drug Metab. Toxicol. 12(3), 327-344 (2016).

9. Gyrolab ADA solution (2012). www.gyros.com

10. Multi-array assay system - bridging immunogenicity assays - guidelines for assay development (2011). www.mesoscale.com

11. Wadhwa M, Knezevic I, Kang HN, Thorpe R. Immunogenicity assessment of biotherapeutic products: an overview of assays and their utility. Biologicals 43(5), 298-306 (2015).

12. Shankar G, Devanarayan V, Amaravadi L et al. Recommendations for the validation of immunoassays used for detection of host antibodies against biotechnology products. J. Pharm. Biomed. Anal. 48(5), 1267-1281 (2008).

13. Immunogenicity testing of therapeutic protein products - developing and validating assays for anti-drug antibody detection (2019). www.fda.gov

14. Guideline on bioanalytical method validation (2012). www.ema.europa.eu

15. Trambas C, Lu Z, Yen T, Sikaris K. Depletion of biotin using streptavidin-coated microparticles: a validated solution to the problem of biotin interference in streptavidin-biotin immunoassays. Ann. Clin. Biochem. 55(2), 216-226 (2018).

16. The FDA warns that biotin may interfere with lab tests: FDA safety communication (2017). www.fda.gov/medicaldevices/safety/alertsandnotices/ucm586505.htm 